\title{
Rating Agencies, Self-Fulfilling Prophecy and Multiple Equilibria? An Empirical Model of the European Sovereign Debt Crisis 2009-2011
}

\author{
Manfred Gärtner (Corresponding author) \\ School of Economics and Political Science, University of St. Gallen, Switzerland \\ E-mail: manfred.gaertner@unisg.ch
}

Björn Griesbach

Swiss National Bank, Zurich, Switzerland

E-mail: bjoern.griesbach@snb.ch

Received: October 17, 2016 Accepted: December 2, 2016

doi:10.5296/ber.v7i1.11166 URL: http://dx.doi.org/10.5296/ber.v7i1.11166

\begin{abstract}
We explore whether governments may have faced scenarios of self-fulfilling prophecy and multiple equilibria during Europe's sovereign debt crisis. To this end, we estimate the effect of interest rates and other macroeconomic variables on sovereign debt ratings, and of ratings on interest rates. We detect a nonlinear effect of ratings on interest rates which is strong enough to permit multiple equilibria. The good equilibrium is stable, ratings are excellent and interest rates are low. A second unstable equilibrium marks a threshold beyond which the country slides towards an insolvency trap. Coefficient estimates suggest that countries should stay well within the A segment of the rating scale in order to remain safe from being driven towards default.
\end{abstract}

Keywords: eurozone, crisis, sovereign debt, credit spreads, bond yields, rating agencies, multiple equilibria, self-fulfilling prophecy.

JEL classification: F3, G24, H6. 


\section{Introduction}

The Eurozone's sovereign debt woes rekindled interest in the market for government bonds. Internet blogs became alive with conjectures of multiple equilibria and self-fulfilling prophecy as key characteristics of Europe's debt crisis. ${ }^{1}$ Policy discussions followed, offering advice as to what recipes could work in situations where good and bad equilibria in the market for government bonds exist side by side. ${ }^{2}$ Academic journals feature a growing list of refined models that may generate multiple equilibria. While interest in this topic existed well before the Great Recession, it intensified while the twin crises gained traction. ${ }^{3}$ A perceived vulnerability of this market to errors or abuses also spawned reactions by regulators. Most prominently, the European Commission's new regulation on credit rating agencies (CRAs) entered into force on 20 June 2013, and ESMA, the European Securities and Markets Authority, identified deficiencies in sovereign ratings processes on 2 December 2013 and insisted on remedial action by CRAs. ${ }^{4}$

This brings CRAs into the picture which, even well before the outbreak of the financial crisis, had been widely considered to be "among the most powerful voices in today's capital markets" (The Economist, 2005). Their subdued treatment in academic research is puzzling, however. While, quite generally, little direct empirical work has been forwarded that looks at the existence and nature of multiple equilibria in Europe's recent financial turmoil, interest in the ratings agencies' role in these developments is virtually non-existent. This paper takes a step in this direction.

The empirical work presented in this paper is rooted in Calvo's (1988) seminal analysis of government debt which proposes a positive feedback-loop between interest rates on government debt and default risk. This may generate multiple equilibria in the market for government bonds and make perceptions of default risk self-fulfilling. We estimate a modification of the model which assumes that markets accept sovereign debt ratings as a measure of default risk. Our quantitative results of how ratings affect interest rates, and how interest rates, along with a vector of fundamentals such as debt ratios and deficits, affect ratings, do indeed point towards the possibility of multiple equilibria. A good and a bad equilibrium exist. Both are locally stable. Stable neighborhoods are separated by a third, unstable equilibrium, which constitutes a threshold on the rating scale beyond which a self-propelling downward spiral may even drive countries with initially healthy fundamentals towards default. The fact that market misperceptions or erroneous downgrades may trigger such a process is camouflaged by its self-fulfilling nature, during which erroneous perceptions or downgrades create the very economic and financial conditions that they predicted.

Multiple equilibria and self-fulfilling prophecies with respect to the recent sovereign debt crisis are addressed in Schumacher (2014), Aizenman et al. (2013b), De Grauwe and Ji

\footnotetext{
For pertinent contributions see Krugman (2011), De Grauwe and Ji (2012) or The Economist (2011).

2 A classic is Krugman (1996). More directly on debt crises are Calvo (1988), Cole and Kehoe (2000) and, on the European debt crisis, De Grauwe (2011) and Gros (2011).

3 See, for example Gerlach (2010) and De Grauwe (2011)

${ }^{4}$ See European Commission (2013) and ESMA (2013).
} 
(2012), De Grauwe and Ji (2013), von Hagen et al. (2011), and Blanchard (2011). Besides, some contributions discuss the role of sovereign debt ratings during the recent crisis. Arezki et al. (2011), Gärtner et al. (2011) and Aizenman et al. (2013a) find a significant effect of sovereign rating news on credit markets during 2007-2010. This is in line with results provided by Kiff et al. (2012), who find that ratings affect the cost of funding of sovereign issuers and are, therefore, a threat to stability in sovereign bond markets. For research regarding the effect of fundamentals on the pricing of sovereign debt without sovereign debt ratings, see Beirne and Fratzscher (2013) and Beetsma et al. (2013).

Section 2 describes Romer's (2012) adaption of the Calvo (1988) model, which provides the basis for our empirical analysis, and discusses estimation results. Section 3 presents some refinements and an analysis of insolvency thresholds beyond which default appears unavoidable without outside help. Lessons are drawn in Section 4, and Section 5 concludes.

\section{An Empirical Model of the Government Bond Market}

The backbone for our empirical analysis is provided by Romer's (2012) structural adaption of Calvo's (1988) optimizing model of sovereign debt crises. Drawing on Calvo, Romer represents the market for government bonds by means of two equilibrium conditions. One says how default risk affects the risk premium and, thus, the interest rate that a country pays on its debt. The other one states how this interest rate and other economic (and political) variables bear on a government's propensity to default. Our empirical model expands the Calvo-Romer scenario in three ways:

First, sovereign bond ratings are taken as a measure of the default probability of sovereigns. This variable is easily observed and measured. It also permits a discussion of how errors or biases in sovereign bond ratings may affect the dynamics of a sovereign debt crisis.

Second, financial markets are assumed to use sovereign debt ratings as an indicator of sovereigns' default probabilities. The attached credibility need not be perfect. What we need for the derived results to hold is that financial investors respond to rating changes, either because they believe that it adds to their own information set, or because regulations or incentive structures force them to respond.

Third, we look beyond rational expectations equilibria, acknowledging evidence of how expectations may be formed in financial markets during normal times ${ }^{5}$ and recognizing the often expressed view that markets in the aftermath of the financial crisis appeared to be driven by panic and fear, or even schizophrenia. ${ }^{6}$ This brings bandwagon and herd behaviour as well as institutional influences into the picture. While this does not affect the model's

\footnotetext{
${ }^{5}$ See Haruvy et al. (2007, p. 1901) who's laboratory experiment suggests that "individual's beliefs about prices are adaptive". More direct evidence of a striking lack of rationality in financial markets is reported in Xia and Strobl (2012), who show that an issuer-pays model leads to "both statistically and economically significant" (p. 24) rating inflation, but that "investors do not seem to adjust for any bias in pricing issuers' securities" (p. 24).

${ }^{6}$ These include both successful practitioners and eminent academics. Soros (2012), a legend in investment circles, quips: "I am not well qualified to criticize the theory of rational expectations and the efficient market hypothesis because as a market participant I considered them so unrealistic that I never bothered to study them." Two of the four hard truths that the IMF chief economist Blanchard (2011) learned from 2011, directly bear on this. His number three is: "financial investors are schizophrenic about fiscal consolidation and growth". And the fourth reads: "Perception moulds reality". See also Arezki et al. (2011).
} 
equilibria, it permits a richer set of dynamics.

The empirical model mimics the two structural equations of the Romer model:

First, current interest rates $i$ on government debt titles are driven by movements of the risk-free rate $i^{*}$ and the risk-premium that separates the two rates. Using sovereign debt ratings $r$ as an indicator of default risk, the interest rate for our empirical work becomes ${ }^{7}$

$$
i-i^{*}=\Omega(r) \text { with } \Omega_{r}>0
$$

Second, the probability of default, as approximated by sovereign bond ratings, is affected by the ability and willingness to service the outstanding debt. This, in turn, reflects a set of observable macroeconomic and political variables. This set includes the effective interest rate $i^{\text {eff }}$ a country pays on outstanding debt. In contrast to the Romer model, in which the effective interest rate equals the current interest rate because the government only issues one-period bonds, real-world governments issue debt titles with longer maturities that may extend to 30 years or more. Letting the maximum maturity of any country in the sample be $m$ and comprising fundamentals into a vector $\mathbf{N}$, the rating equation reads

$$
r=\Pi\left(i^{e f f}, N\right)=\Pi\left(\sum_{j=0}^{m} \alpha_{j} i_{-j}, N\right) \text { with } \Pi_{i}>0
$$

where $\alpha_{-1}$ is a weight coefficient reflecting the share of a country's sovereign debt issued at lag $j$. Regarding the variables to be included in $\mathbf{N}$ we draw on three sources:

1. The starting point is the standard debt dynamics equation that shows the debt ratio to be driven by the primary balance, the interest rate, inflation, aggregate income and economic growth. ${ }^{8}$

2. In addition, we experiment with additional variables identified in previous research as robust drivers of sovereign debt ratings. ${ }^{9}$

3. A third source are the key variables listed on the rating methodology sites of major rating agencies. ${ }^{10}$

This provides us with a comprehensive set of fundamentals. Elimination of variables that neither make a significant and robust statistical contribution nor form an integral part of the employed theoretical model, renders the parsimonious subset of fundamentals employed in

\footnotetext{
${ }^{7}$ We abstain from adjusting for forward exchange rates, as we use foreign currency ratings for our analysis which include potential exchange rate risk. As a robustness test, we also ran the regressions on eurozone countries, only, and the results did not change substantially. See Appendix 1 for the respective regression results.

${ }^{8}$ See Escolano (2010).

9 See Cantor and Packer (1996), Ferri et al. (1999), Mellios and Paget-Blanc (2006) and El-Shagi (2010) who all report regressions on sovereign debt ratings explained by fundamentals. See also the discussion on the selection of variables in Gärtner et al. (2011) who use the same set of variables as we do here. Some variables used in other studies are omitted. For example, the default history does not play a role in our sample, since none of the selected OECD countries has declared default after World War II. Following the literature, we also abstain from using forward looking variables such as expected growth rates. Rating agencies emphasize that they do not build their judgments on short run business cycle fluctuations. Hence, it is plausible to rather use trends of variables, especially when they are highly volatile, than short run forecasts.

${ }^{10}$ Rating agencies remain secretive about their true procedures. In their sovereign ratings methodology Fitch.(2011) claims to use 148 groups of variables for their rating assessment. However, agencies do not provide a precise answer as to how they aggregate all that information into a single variable.
} 
the rest of the paper.

A direct empirical implementation of the rating equation (2) would require the inclusion of long vectors of interest rates, lagged up to several decades. We refrain from doing this because this would lead to a substantial reduction in the degrees of freedom in our estimation equation, effectively ruling out some of the robustness tests reported in Appendix 1. Also, because interest rates are highly persistent, serious multi-collinearity issues would creep in and contaminate results. In order to avoid this, we opt for two parsimonious specifications of the proposed model:

One version approximates the effective interest rate $i^{\text {eff }}$ by the average interest rate of the preceding year $\bar{i}_{-1}$. This has the advantage of rendering the model recursive and generating explicit dynamics. But it leaves results vulnerable to the criticism of suffering from simultaneous equations bias. This is a valid point, in principle. In practical terms it may not matter too much because the current interest rate constitutes only a small fraction of a country's effective interest rate. Thus any change in the current interest rate affects the effective interest rate very slowly, via substantial lags.

As a counterpoint, and in order to gauge to what extent this recursive specification biases regression coefficients, we also estimate a simultaneous-equations version of the model. This specification uses the current interest rate as a proxy for the effective interest rate in the rating equation. This may be justified by assuming that the current interest rate exerts a dominant effect on expectations of future interest rates, rendering it the key driver of perceived default risk as measured by sovereign debt ratings. This takes care of the simultaneous-equations issue. It has the drawback, though, of depriving the model of any dynamics. We will return to this issue in section 3.

\subsection{The Data}

The empirical analysis uses annual data for 25 OECD countries for the period 1999 to $2011 .^{11}$ Nine OECD members were omitted because no data was available or because they became members after 1999. We chose this specific period because sovereign ratings for the observed countries are not always available before then, and in order to avoid the structural break due to the introduction of the Euro in 11 countries of our sample. We chose not to expand the time horizon beyond 2011 because Greece officially defaulted in 2012 by writing off a large amount of its outstanding debt via a so called haircut. As motivated in the previous section, we include the following variables in our regressions. Descriptive statistics are shown in Table 1.

- Sovereign debt rating: Three major agencies provide sovereign ratings: Moody's, Fitch Ratings and Standard \& Poor's. We use end-of-year, long-term foreign currency sovereign debt ratings of Fitch Ratings. ${ }^{12}$ For our analysis we convert the ratings into an equidistant

\footnotetext{
${ }^{11}$ Our sample includes Australia, Austria, Belgium, Canada, Czech Republic, Denmark, Finland, France, Germany, Greece, Hungary, Ireland, Italy, Japan, Netherlands, New Zealand, Norway, Poland, Portugal, South Korea, Spain, Sweden, Switzerland, United Kingdom, and the USA.

${ }^{12}$ Since the data needed for our analysis were not available for all three agencies we settled for Fitch as a representative. Given the high correlation between the ratings of the three big rating agencies, we do not expect this choice to bear on our
} 
numerical scale running from 1 for $\mathrm{AAA}$ to 21 for $\mathrm{D}$ following other studies on rating agencies, such as Afonso et al. (2007).

- GDP growth: Data on real GDP growth is from the OECD Economic Outlook No. 90 Annex, Table 1. Following the literature, we use three year averages which reflects the agencies' approach to take out the business cycle effect when deciding on a sovereign rating. ${ }^{13}$

- GDP per capita: Real GDP per capita measured in thousand current international dollars is from the IMF World Economic Outlook database.

- Budget surplus: This variable measures general government financial balances as a percentage of nominal GDP and includes one-off factors such as sales of mobile phone licenses. The source is Annex Table 27 of the OECD Economic Outlook No. 90.

- Primary surplus: This variable measures the general government underlying primary balance as a percentage of potential GDP. It equals government surplus less net interest payments and is adjusted for one-off factors. The source is Annex Table 30 of the OECD Economic Outlook No. 90.

- Debt ratio: General government gross debt as a percentage of nominal GDP is taken from Annex Table 32 of the OECD Economic Outlook No. 90.

- Inflation: Consumer price inflation is taken from Annex Table 18 of the OECD Economic Outlook No. 90.

- Bond yield: This is the annual average of monthly 10-year generic government bond yields as provided by Bloomberg.

- Credit spread: The credit spread is calculated as the difference between the December value of the monthly 10-year generic government bond yield of a country and that of Germany.

Table 1. Descriptive statistics

\begin{tabular}{|l|l|l|l|l|l|}
\hline & Mean & Median & Std. Dev. & Maximum & Minimum \\
\hline Sovereign debt rating $(r)$ & 2.7 & 1.0 & 2.5 & 18.0 & 1.0 \\
\hline GDP growth & 2.2 & 2.3 & 1.9 & 9.0 & -4.3 \\
\hline GDP per capita & 30.9 & 30.5 & 8.1 & 53.4 & 11.1 \\
\hline Budget surplus & -1.7 & -2.0 & 5.3 & 19.1 & -31.3 \\
\hline Primary surplus & -0.4 & -0.1 & 3.0 & 6.9 & -8.2 \\
\hline Debt ratio & 68.2 & 61.1 & 34.4 & 211.7 & 13.7 \\
\hline Inflation & 2.3 & 2.3 & 1.5 & 9.8 & -1.7 \\
\hline Bond yield $(\bar{i})$ & 4.6 & 4.4 & 1.7 & 19.1 & 1.0 \\
\hline Credit spread $\left(i-i_{D}\right)$ & 0.8 & 0.3 & 2.5 & 33.1 & -3.6 \\
\hline
\end{tabular}

main results. Note that, for example Gaillard (2011) reports pairwise correlation coefficients between the three rating agencies above 0.97 during 2000 until 2010.

13 See, for example, Afonso et al. (2007). 


\subsection{Estimating the Rating Equation}

We start with the rating equation (2), which attempts to quantify how interest rates on government bonds and other economic variables affect the probability of default as measured by the credit rating of the country. Regression results for the recursive and the simultaneous-equations specification of our model are given in Table 2

Table 2. The rating equation. Endogenous variable: sovereign debt rating $r$. Annual data for 25 OECD countries, 1999-2011

\begin{tabular}{|c|c|c|}
\hline & (I) OLS & (II) 2SLS \\
\hline Constant & 1.214 & 1.432 \\
& $(2.408)$ & $(0.944)$ \\
\hline GDP growth & -0.049 & $0.110^{*}$ \\
& $(0.105)$ & $(0.066)$ \\
\hline GDP per capita & $-0.118^{* * *}$ & $-0.116^{* * *}$ \\
& $(0.037)$ & $(0.015)$ \\
\hline Budget surplus & -0.013 & 0.007 \\
& $(0.053)$ & $(0.021)$ \\
\hline Debt ratio & $0.022^{* * *}$ & $0.015^{* * *}$ \\
& $(0.008)$ & $(0.003)$ \\
\hline Primary surplus & $-0.141^{* * *}$ & $-0.232^{* * *}$ \\
& $(0.070)$ & $(0.033)$ \\
\hline Inflation & $0.178^{*}$ & 0.053 \\
& $(0.105)$ & $(0.078)$ \\
\hline $\bar{i}_{-1 \cdot}$ & $0.693^{* * *}$ & - \\
\hline$i$ & $(0.219)$ & $0.742^{* * *}$ \\
& - & $(0.110)$ \\
\hline$R^{2}$ & & 0.686 \\
\hline Adjusted $R^{2}$ & 0.608 & 0.678 \\
\hline Observations & 0.598 & 291 \\
\hline
\end{tabular}

Pooled OLS and 2SLS regressions. Heteroscedasticity and autocorrelation robust standard errors in parentheses as documented in Zeileis (2004). *,**,*** denote significance at the 10\%, 5\%, $1 \%$ levels. year $\bar{i}$ denotes annual average of government bond yields. Ratings are transformed into an equidistant numerical scale from 1 (AAA) to 21 (D), see Appendix 2 for entire table. Instruments used in the simultaneous estimation of equations (1) and (2) (include linear and cubic terms of all exogenous variables. Variables included in vector $\mathrm{N}$ help identify the shape of the interest rate line. The German interest rate, representing the risk-free rate and used in the interest rate equation with a coefficient of 1 , helps identify the shape of the rating line

The first column relates to the recursive specification of the model. It shows estimates of the rating equation using ordinary least squares (OLS) with the lagged interest rate being used as a proxy for the effective interest rate on government debt. Sovereign bond ratings are found 
to depend on the macroeconomic indicators typically used in pertinent empirical research and mentioned by rating agencies, as explained above. This robust set of indicators explains 60 percent of the variance of sovereign bond ratings between countries and over time in our panel. All estimated coefficients possess the expected sign, though not all are significantly different from zero. Ratings improve with higher income levels and growth, or with better overall and primary budget situations. Ratings deteriorate when the debt ratio, inflation or the interest rate go up.

Given that the possibility and nature of multiple equilibria depend on the functional forms of the model's structural equations, a crucial question is whether the relationship between ratings and the (lagged) interest rate is linear or not. Applying the test proposed in Davies (1987), the null hypothesis of a constant slope coefficient over the entire data range could not be rejected. In the same vein, non-linear functional relationships, such as using a logarithmic, exponential or hyperbolic transformations of $i$, resulted in inferior fits of the regression equation. This suggests that the ratings curve of our model may be considered linear within the range covered by our panel data. ${ }^{14}$

As mentioned above, the estimates obtained from a recursive implementation of our model of the market for government bonds may be affected by simultaneous equations bias caused by the immediate feedback from the interest rate to the sovereign debt rating. ${ }^{15}$ In order to gauge whether and how simultaneous equations bias may affect OLS estimates, the second column in Table 2 shows the estimates obtained from a two-stage least squares regression (2SLS). The underlying model differs from the recursive specification reported in the first column by using the current interest rate as a regressor instead of the lagged one.

The 2SLS estimate of the rating equation features a noticeably improved coefficient of determination. The coefficient on the interest rate, which is crucial for our purposes, is virtually the same, with the 2SLS rating line being marginally flatter than the OLS rating line when depicted in the r-i diagram to be used below (see Figure 1).

Among the exogenous variables, the key determinants of a country's financial situation, the debt ratio and the primary surplus ratio, remain highly significant, though the coefficient estimate falls by a third in the first case and increases by about a third in the second case. As regards other variables that bear on the comparative statics of the model, GDP per capita remains unaffected, but inflation turns insignificant, while GDP growth is now significant at the $10 \%$ level, albeit with the wrong sign.

\subsection{Estimating the Interest Rate Equation}

We now turn to the effect of sovereign bond ratings on (current) interest rate spreads as outlined in equation (1). Baseline results are given in Table 3.

\footnotetext{
${ }^{14}$ We also estimated a generalized additive model (GAM) with penalized regression splines as smoothing terms (see Hastie and Tibshirani (1990) and Appendix 1 for details). The optimal functional form with respect to the interest rate is again a straight line.

15 Another issue is that both the interest rate and the sovereign debt rating may be driven by the same set of fundamentals, presumed to determine default risk, making the detected statistical relationship between $i$ and $r$ spurious. See Appendix 1 for a discussion of these arguments, first from a statistical perspective, and then from an institutional angle.
} 
The regression reported in the first column proposes a simple linear relationship between the interest rate and the sovereign debt rating and serves as a reference point. It suggests that an

Table 3. The interest rate equation. Endogenous variable: credit spread of government bonds $i-i_{D}$. Annual data for 25 OECD countries, 1999-2011

\begin{tabular}{|c|c|c|c|}
\hline & (III) OLS & (IV) OLS & (V) 2SLS \\
\hline Constant & $-0.961^{* *}$ & $0.228^{* *}$ & $0.164^{* *}$ \\
& $(0.482)$ & $(0.100)$ & $(0.083)$ \\
\hline$r$ & $0.657^{* * *}$ & - & - \\
& $(0.213)$ & & $0.007^{* * *}$ \\
& - & $0.006^{* * *}$ & $(0.000)$ \\
\hline$r^{3}$ & & $(0.000)$ & 0.768 \\
\hline$R^{2}$ & 0.420 & 0.799 & 0.767 \\
\hline Adjusted $R^{2}$ & 0.418 & 0.798 & 291 \\
\hline Observations & 291 & 291 & \\
\hline
\end{tabular}

The notes to Table 2 apply.

AAA rated country, which translates into a numerical value of 1 for the rating variable, may expect an interest rate spread versus Germany of $-0.961+0.657=-0.304$. Any downgrade by one notch raises this country's interest rate by 65.7 basis points. This equation explains 42 percent of the variance in the credit spreads in our sample.

Repeating what we did with the rating equation, we tested the null hypothesis of a constant slope coefficient as it is assumed in this first regression of Table 3. Applying the test proposed in Davies (1987), the null was rejected and the break point was suggested to lie between a $\mathrm{BBB}+$ and a BBB rating. ${ }^{16}$ The differences between the slopes in the two segments are striking, with the coefficients differing by a ratio of ten to one. While, on average, a rating downgrade by one notch in the range between AAA and A- raises the interest rate by 0.3 percentage points, a downgrade by one step raises the interest rate by 3.12 percentage points if the rating is in B territory or below.

Since the null hypothesis of a constant slope coefficient was rejected, we tested different functional forms to obtain a parsimonious representation of how ratings affect spreads. Unsurprisingly, any function that permits a convex shape of the interest rate line, as suggested by the piecewise regression derived from the Davis test, generates a significantly improved fit of the estimation equation. It turns out that a third order polynomial provides the best results from a goodness-of-fit perspective. Matters are simplified by the fact that the first-order and second-order terms are not significant at conventional levels. Thus, we are left with the simple regression reported in the second column of Table 3. This shows that raising ratings to their third power, rather than employing them linearly, almost doubles the adjusted coefficient

\footnotetext{
${ }^{16}$ For the employed methodology see Davies (1987) and Muggeo (2003). Regressions were run using the R package provided in Muggeo (2008) adjusted for heteroscedastity and serial correlation according to Newey and West (1987) and Zeileis (2004).
} 
of determination. ${ }^{17}$ The implied non-linearity is substantial: depriving a country of its AAA status, downgrading it by one notch, raises the interest rate by 0.050 percentage points only. Doing the same thing to a $\mathrm{BBB}+$ country raises the interest rate by 1.490 percentage points. But if a country with a CCC+ rating slides down one more step, the interest rate its creditors require increases by a whopping 5.864 percentage points.

The third column reports the 2SLS result. ${ }^{18}$ Differences are marginal, with the 2SLS curve being positioned slightly lower than the OLS line (as signaled by the constant term, measuring the spread versus the 'risk free' German interest rate, of 0.164 versus 0.228 ) but also slightly steeper (with the slope coefficient for $r^{3}$ being 0.007 compared to 0.006 ). The 2SLS equation also has a slightly inferior fit of 0.767 .

The virtually identical estimates of the interest rate and rating equations provided by the OLS and 2SLS procedures imply that the recursive and the simultaneous-equations model yield effectively identical outcomes regarding the crucial issue of multiple equilibria. Differences or question marks only occur with respect to the at best marginally significant comparative static effects of inflation and GDP growth. What the 2SLS estimates may be hiding, however, is the dynamics of the model proposed by the recursive specification. A host of studies on causality and interaction between sovereign ratings and interest rates based on higher frequency data suggests that the non-existence of a dynamic structure in our simultaneous-equations specification may be a statistical artifact that should be attributed to the fact that intra-year dynamics is lost in an empirical model built from annual data. ${ }^{19}$

\subsection{Multiple Equilibria and Self-Fulfilling Prophecy}

We now return to our key question of whether the developments observed during Europe's sovereign debt crisis support the notions of self-fulfilling prophecy and multiple equilibria. In order to keep dynamics on our radar, we focus on the recursive specification of our model. This specification's equilibrium properties appear to be robust, as the 2SLS results and the robustness tests provided in Appendix 1 suggest. ${ }^{20}$ The implied dynamics may miss the finer aspects of intra-year interaction. Given the robustness of the estimated equilibrium properties, however, the recursive version should provide us with a useful idea of the stability of identified equilibria and the trajectory from one equilibrium to the next.

Figure 1 visualizes the $r$ and $i$ lines from our estimated model. The $r$ line is derived from the first regression in Table 2. The $i$ line represents the second regression of Table 3 which uses a third-order polynomial term for the sovereign debt rating. The estimated credit-spread equation is solved for the interest rate by adding the average German interest rate to obtain the respective $i$ line. The position of the $r$ line is determined by a set of exogenous variables, which are different for each country and which change over time. To allow for a synthesized

\footnotetext{
17 As with the rating equation in section 2.2, we also estimate a generalized additive model (GAM) with penalized regression splines as smoothing terms (see Hastie and Tibshirani (1990) and Appendix 1 for details). The results indicate that using a third order polynomial is the best fitting functional form.

18 The estimation procedure follows Chapter 9.5 in Wooldridge (2002) on simultaneous equation models that are non-linear in their endogenous variables. As proposed, we use linear and cubic terms of all exogenous variables as instruments.

19 Since several variables, such as debt ratios and deficits, are only available on an annual basis, we have to work with yearly data, here.

${ }_{20}$ Appendix 1 shows fixed effect regressions, an analysis of eurozone countries, only, and cross sectional estimates.
} 


\section{Macrothink}

general discussion, these exogenous variables are set to their average values in our panel data set to position the bold $r$ line in Figure 1 .

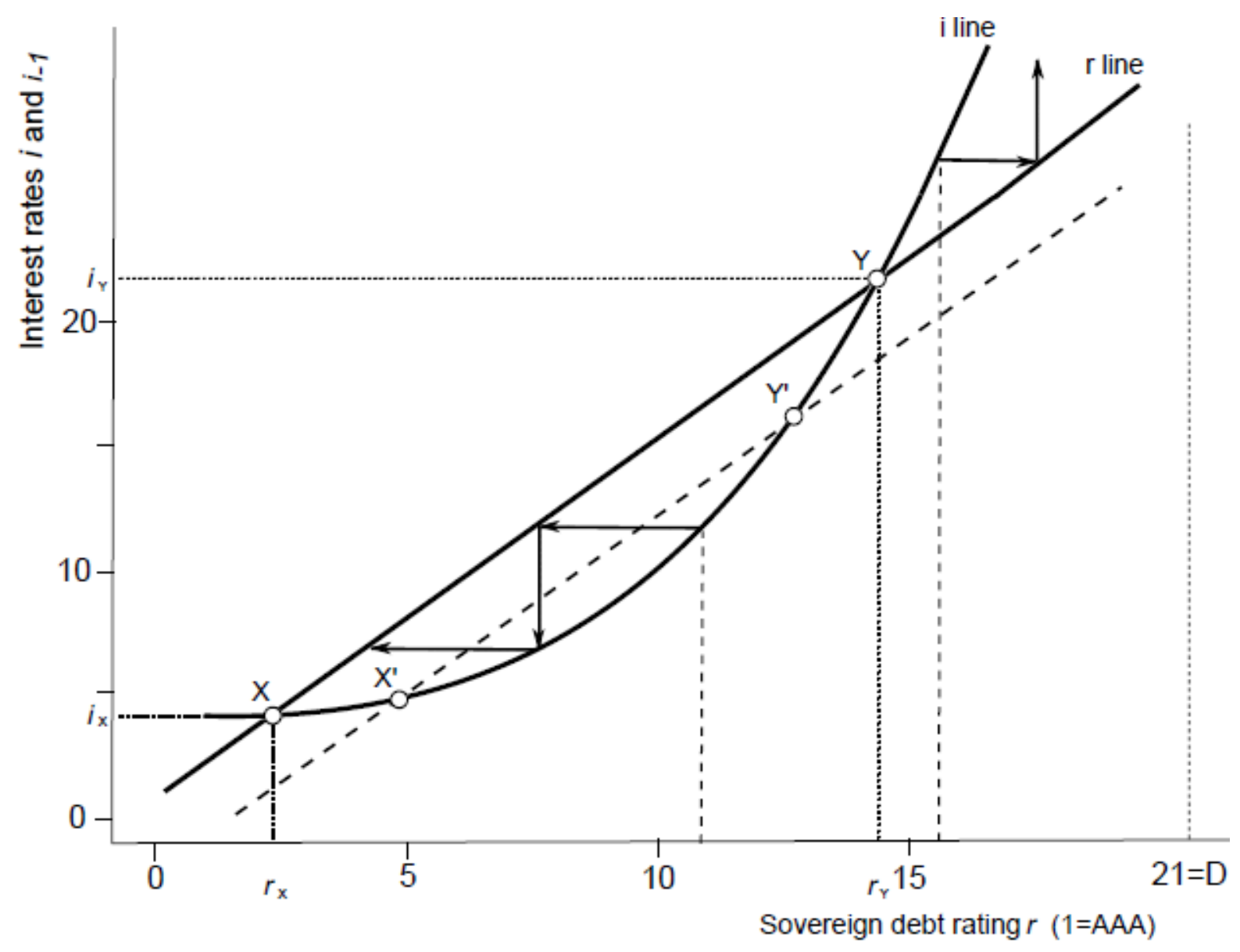

Figure 1. The empirical model

When curves are positioned like the solid lines, the model possesses three equilibria. Two of these are points of intersection between the lines, marked $X$ and $Y$. Point $X$ is a 'good' equilibrium in which the interest rate is low, which, at given fundamentals, justifies an excellent credit rating. The second equilibrium, at point $Y$, implies a substantial spread between the interest rate the government pays and the risk-free alternative, reflecting a significant risk of default and, consequently, a credit rating at the low end of the B segment of the rating scale. The third, 'bad' equilibrium, located in the North-Eastern corner of the diagram, is a degenerated one, with characteristics similar to a black hole. It cannot be identified as a point because the market for this country's debt titles has broken down and no interest rate is determined.

Given the dynamics implied by the recursive nature of our model, point $Y$ marks an unstable equilibrium. It separates the neighborhoods within which the first and the third equilibrium are locally stable. To illustrate this, suppose the country initially enjoys the good equilibrium $X$. Now let the rating agency make a non-recurring mistake, as it would be captured by the 
regressions error term, and publish a rating that sits between $r_{X}$ and $r_{Y}$. While this drives the interest rate up, as suggested by the $i$ line, this does not suffice to actually justify the rating. Therefore, the rating will be reduced next period, which, in turn, lowers the interest rate, reduces the rating again, and the market eventually resettles into equilibrium point $X$ again. The opposite happens if the rating, erroneously or arbitrarily, is set to a value above the threshold $r_{Y}$. Such a downgrade generates an increase in the interest rate that not only provides justification for the initial downgrade, but calls for another downgrade. Left alone, this self-propelling process drives the country closer and closer towards default. In this sense the unstable equilibrium Y constitutes an insolvency threshold, marking the edge of an abyss from which there is no endogenous return.

In order to answer the question posed in this paper's title, the analyzed set of data suggests that the market for government bonds

1. may have more than one equilibrium, and that one of these would constitute sovereign default; and

2. may be susceptible to self-fulfilling prophecy in the sense that even unjustified rating downgrades, or market beliefs in general, may partly or fully, temporarily or permanently, generate the very conditions that justify the rating or belief.

Whether these problems actually arise, needs to be explored by looking at country-specific data. If a country has worse than average fundamentals that put its rating line into the dashed position, this has two comparative static consequences: It moves the good equilibrium in a north-easterly direction, triggering downgrades and raising the interest rate. And it moves the insolvency threshold to the left, thus increasing the country's risk of being pushed into the self-propelling maelstrom towards default. This would also happen, for example, if instead of a one-time error a permanent bias crept into the rating equation. Once the $r$ line sits so low as to loose contact with the $i$ line, the good equilibrium vanishes and all paths point towards default.

The empirics of our model permit two kinds of self-fulfilling prophecy: To the left of the insolvency threshold rating errors are not fully self-fulfilling and, therefore, affect the market only temporarily. To the right of the threshold, rating errors cause an overreaction of the interest rate that triggers a snowball effect of successive downgrades and rising interest rates and ends in default.

\section{Refinements}

This section moves beyond the model described in section 2 . The estimates provided by the regressions VI and VII of Table 4 derive from a more flexible interpretation of the Romer model.

Regression VI explores the hypothesis of whether any change in its sovereign rating that brings a country into the news and thereby unsettles financial markets, has an additional effect on interest rates. This effect may be independent of the actual debt rating of a country, and would bear on interest rates only during the period in which the downgrade was 
announced and, thus, constituted news. Augmenting our equations by an explanatory variable $\Delta r$ does indeed generate a highly significant coefficient and the coefficient of determination increases from 0.798 to 0.811 .

Table 4. Refining the interest rate equation. Endogenous variable: credit spread of government bonds $i-i_{D}$. Annual data for 25 OECD countries, 1999-2011

\begin{tabular}{|c|c|c|c|}
\hline & $(\mathrm{IV})$ & $(\mathrm{VI})$ & $(\mathrm{VII})$ \\
\hline Constant & $0.228^{* *}$ & $0.265^{* *}$ & $0.223^{* *}$ \\
& $(0.100)$ & $(0.105)$ & $(0.104)$ \\
\hline$r^{3}$ & $0.006^{* * *}$ & $0.005^{* * *}$ & 0.005 \\
& $(0.000)$ & $(0.000)$ & $(0.000)$ \\
\hline$\Delta r$ & - & $0.504^{* * *}$ & - \\
\hline \multirow{2}{*}{$\Delta r^{+}$} & - & $(0.154)$ & $0.732^{* * *}$ \\
& & - & $(0.168)$ \\
\hline \multirow{2}{*}{$\Delta r^{-}$} & - & - & -0.047 \\
\hline$R^{2}$ & & & $0.196)$ \\
\hline Adjusted $R^{2}$ & 0.799 & 0.813 & 0.818 \\
\hline F & 782.865 & 0.811 & 0.816 \\
\hline Observations & 291 & 534.044 & 539.954 \\
\hline
\end{tabular}

Pooled OLS regressions. Heteroscedasticity and autocorrelation robust standard errors in parentheses as documented in Zeileis (2004). *, **, *** denote significance at the 10\%, 5\%, $1 \%$ levels. $r$ denotes sovereign debt rating. Ratings are transformed into an equidistant numerical scale from 1 (AAA) to 21 (D). See Appendix 2 for entire table. $\Delta r=r-r_{-1}$ denotes rating changes. $\Delta r^{+}=\max (0, \Delta \mathrm{r})$ denotes downgrades, whereas $\Delta r^{-}=$ $\min (0, \Delta r)$ denotes upgrades, only. Regression IV is repeated for convenience.

Regression VI explores the hypothesis of whether any rating change that brings a country into the news and unsettles financial markets has an additional effect on interest rates. This effect may be independent of the actual debt rating of a country, and would bear on interest rates only during the period in which the downgrade was announced. Augmenting our equations by an explanatory variable $\Delta r$ does indeed generate a highly significant coefficient and the coefficient of determination increases from 0.798 to 0.811 .

It may not come as a surprise that these shock effects are not symmetric. When regression equation VII splits $\Delta r$, which includes rating downgrades as well as upgrades, into $\Delta r^{+}$(i.e. $\Delta r>0$ ) and $\Delta r^{-}$(i.e. $\Delta r<0$ ), the coefficient of determination creeps up still further. The estimated coefficients differ in magnitude and are only significantly different from zero when rating downgrades are announced.

The presence of $\Delta r^{+}$, the coefficient of which carries a $t$-statistic of 4.36 , generates some interesting and potentially disquieting dynamics. The immediate response of the interest rate 
to a rating downgrade is given by ${ }^{21}$

$$
\frac{\Delta i}{\Delta r} \approx 0.015 r^{2}+0.732
$$

Now recall that the slope of the rating line represented by regression $I$ in Table 2 is $1 / 0.693=1.443$. According to equation 3, the interest rate line is steeper than this at levels of $r \geq 6.88$. This means that at sovereign debt ratings outside the lower part of the A-segment, i.e. of A- or worse, a downgrade generates an increase in the interest rate that justifies or more than justifies the initial downgrade, and may trigger a spiral of successive and eventually disastrous downgrades. Only countries in the upper A-segment of the rating scale appear to be safe from this, at least when the shocks to which they are exposed to are only small. However, this only applies when marginal rating shocks occur. Larger shocks, and these have not been the exceptions during Europe's sovereign debt crisis, may even jeopardize countries which were in secure A territory. We may illustrate this by looking at the impulse responses implied by the system of regression equations VII from Table 4 and I from Table 2 for the rating and interest line to shocks of various kinds and magnitudes. This provides us with insolvency thresholds that identify the size of a rating downgrade required to destabilize the public finances of countries with a given sovereign debt rating. Figure 2 summarizes the results.

Figure 2(a) looks at temporary rating shocks, as they would be captured by the error term of our regression equation. The vertical line at a BBB- $(=10)$ rating upwards indicates that the equilibrium is inherently unstable and that the smallest of shocks suffices to trigger an accelerating debt crisis. The outward-sloping segment shows how rating shocks to a country located in the range $\mathrm{BBB}(=9)$ and better need to be increasingly larger to destabilize the country. For example, a country with an $A(=6)$ rating would have to be subjected to an arbitrary downgrade of five notches to a $\mathrm{BB}+(=11)$ rating in order to be pushed beyond the insolvency threshold.

When rating shocks last, however, as has apparently been the case for the eurozone's GIPS ${ }^{22}$ members, much smaller unsubstantiated rating changes may play havoc with government bond markets and suffice to run initially healthy countries into trouble, as shown in Figure 2(b). In this scenario, an arbitrary, yet persistent, downgrade by two notches would trigger a downward spiral in a country with an $A+(=5)$ rating. Rising interest rates would call for further downgrades, which would appear to justify the initial downgrade as an apparently good forecast.

The thresholds depicted in Figure 2 are conservative in the sense that they overestimate the shocks needed to destabilize countries. This is because we were focusing on the interaction between ratings and interest rates alone. All other variables that affect sovereign debt ratings were considered exogenous and thus kept constant during our simulations. In reality, the interest rate hikes that follow rating downgrades will increase budget deficits and debt ratios,

\footnotetext{
${ }^{21}$ This is an approximation, of course, since we are dealing in discrete time.

${ }^{22}$ GIPS (sometimes also referred to as PIGS) is an acronym for Greece, Ireland, Portugal and Spain, the eurozone members that were caught in the eye of the hurricane when Europe's debt crisis climaxed.
} 


\section{Macrothink}

Business and Economic Research

ISSN 2162-4860

2016, Vol. 6, No. 2

and may depress economic activity in general. All this has an additional negative effect on a country's rating, and will thus reinforce the negative tendencies in the country's public finances. With this added transmission channel, even smaller shocks may already suffice to trigger sovereign debt crises.

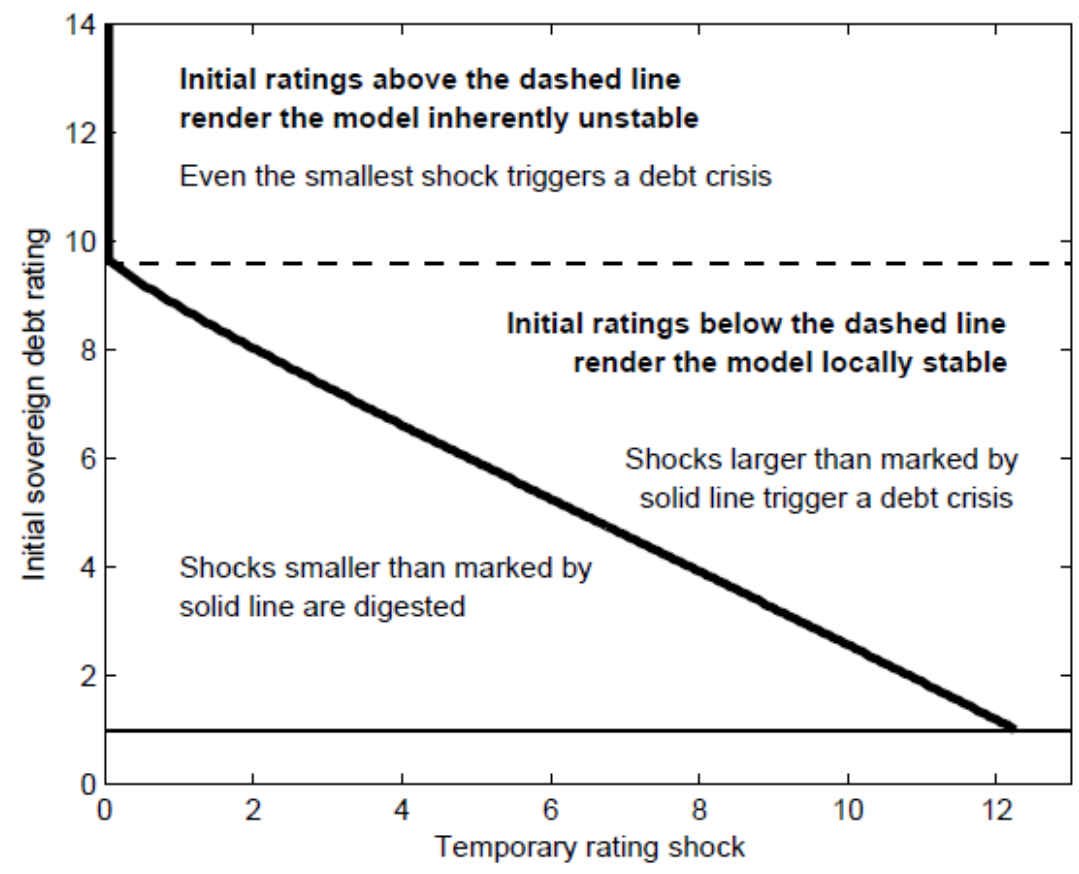

(a) Temporary rating shock.

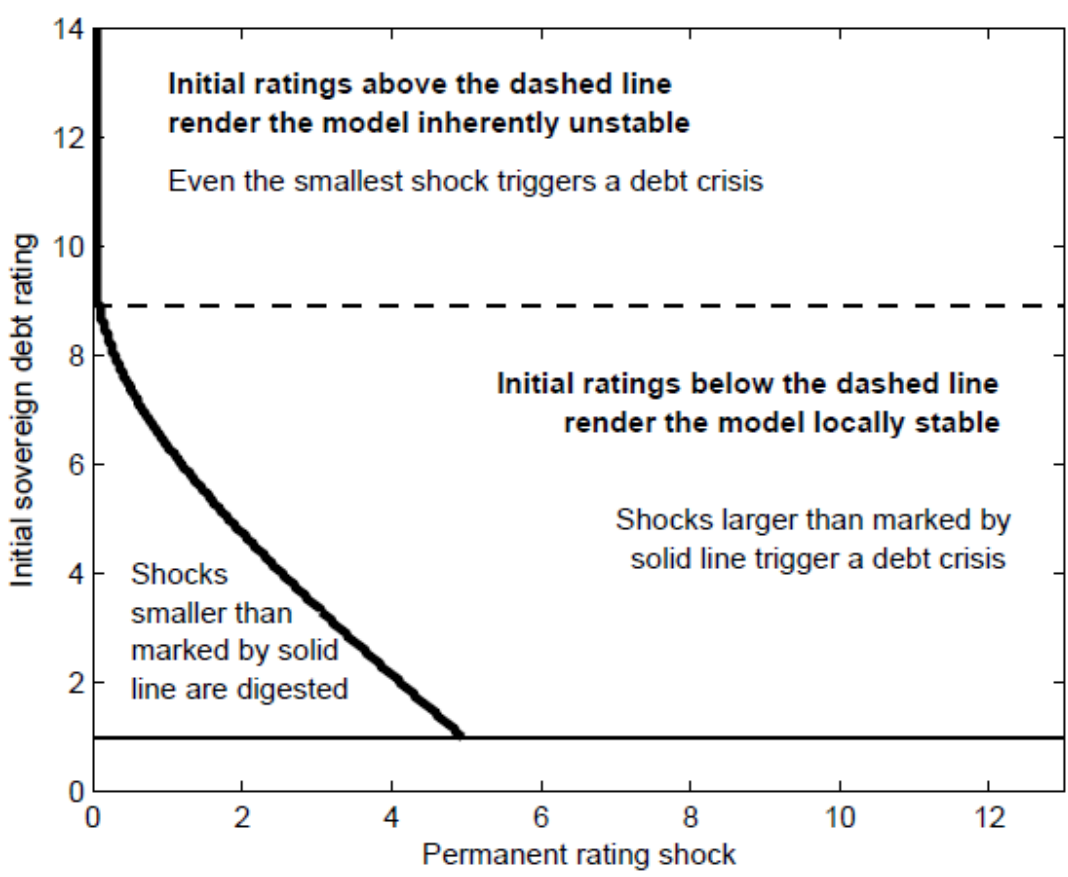

(b) Permanent rating shock.

Figure 2. Insolvency thresholds under temporary and permanent rating shocks 


\section{Lessons}

To the extent that the estimated model summarized in Figure 1 provides a useful description and simplification of the structure, equilibria, dynamics and comparative statics underlying the market for government bonds, sovereign debt crises may stem from two sources:

1. Any temporary or permanent deviation from or shifts of one of the involved curves, as reflected in the error or constant terms of the estimation equations, may drive the country out of an initially stable neighborhood and trigger a crisis. Section 3 looked at rating shocks and the damage they might do.

2. Any changes in the fundamentals that affect the positions of the $i$ line or the $r$ line and, thus, the equilibria, may make a country more vulnerable to a sovereign debt crisis. For instance, any change that increases the risk-free rate, moving the $i$ line up, or shifts the rating line to the right, has two unfavorable effects. First, it renders the good equilibrium less 'good', raising the associated interest rate and credit rating. Second, it moves the insolvency threshold to the left, increasing the risk of being pushed into bankruptcy by unfavorable developments. If the relative effects are strong enough, the interest rate and rating lines may lose contact, making the good equilibrium and the threshold disappear, and rendering insolvency unavoidable.

Section 3 looked at rating shocks and suggested that they may have played a major role in the gestation and propulsion of Europe's sovereign debt crisis. A rating shock of 3.3 notches, to which the GIPS countries were subjected at the start of the crisis, according to Gärtner et al. (2011), would constitute a serious threat to all but the most highly rated countries. At the beginning and during the crisis, however, these risks were aggravated by budgetary and income shocks instigated by the housing and financial crisis. Coefficients from regression I in Table 2 permit a first quantitative assessment of the impact of these shocks on individual countries. Deteriorating fundamentals shifted Portugal's rating curve to the right by 1.1 rating notches in the years 2009 to 2011 . However, the country was downgraded by 8 notches during that time. For Ireland the line shift was 1.3 during those years, but the rating dropped by 7 notches. Fitch lowered the rating of Greece by 12 notches whereas fundamentals would essentially have left the rating curve unchanged. ${ }^{23}$ Note that this experiment looks at the effect of fundamentals (excluding interest rates, which are considered endogenous) via shifts of the rating curve. If we were to consider interest rate changes exogenous, i.e. autonomous drivers of rating changes, the model would predict more pronounced downgrades (Portugal: 1.8 notches downgrade; Ireland: 2.7 ; Greece: 3.6 ). These, however, would still fall massively short of the actual downgrades during those years.$^{24}$

In the context of the results given in Figure 2, this suggests that budgetary and income shocks

\footnotetext{
${ }^{23}$ Note that official statistics regarding the debt level had been tweaked by Greece, the revelation of which led to a complete deterioration of trust by all financial stakeholders including rating agencies. This 'soft factor' is missing from our empirical model, but it certainly played a role in this case. The comparatively modest downgrades that fundamentals predict for Greece are mainly due to a pronounces swing in the primary balance (2008: $-5.2 \%, 2011:+4.1 \%$ ), which mostly offset the effect of the rising level of sovereign debt (2008: 118\%, 2011: 165\%).

${ }^{24}$ For a detailed year-by-year account of what happened in Ireland, with different scenarios for the endogeneity of interest rates, see the narration based on the current paper's empirical model offered in Gärtner et al. (2013).
} 
may have played a minor role only, and that exceptional changes in the risk assessment of the markets and rating agencies may have been a key factor in Europe's debt crisis.

\section{Summary and Conclusions}

This paper analyzed the European sovereign debt crisis that grew out of the global real estate and financial crisis of 2007-2009. Drawing on data for 25 OECD countries for the period between 1999 and 2011, we specifically asked whether there was evidence of multiple equilibria and self-fulfilling prophecy in the market for sovereign bonds. Special attention was given to rating agencies and to non-linearities and dynamics in the interaction between government bond yields and sovereign bond ratings.

We find robust evidence of a non-linear relationship between ratings and interest rates that reflects the theory. This non-linearity is strong enough to generate multiple equilibria. This, in turn, may render rating errors or abuses, or market panic stemming from other sources self-fulfilling in a strict sense. In the implied good and stable equilibrium, ratings are excellent and interest rates are low. A second equilibrium looms, which is unstable. It constitutes a threshold beyond which the country falls into an insolvency trap from which it may only escape by exogenous policy measures or outside intervention.

A more detailed look at the dynamic response of interest rates to rating downgrades revealed that, at least for countries with sovereign debt ratings outside the A range, even small, erroneous rating downgrades may generate the very conditions that do eventually justify the rating. Combined with earlier evidence that many of the rating downgrades of the eurozone's peripheral countries appeared conspicuous and could not be justified on the basis of rating algorithms that explain the ratings of other countries, or ratings in general before 2009, this result is highly discomforting. It urges governments to take a long overdue close look at financial markets in general, and at sovereign bond markets in particular, and at the motivations, qualifications and conflicts of interest of key players in these markets.

\section{Statement}

The views, opinions, findings, and conclusions or recommendations expressed in this paper are strictly those of the author(s). They do not necessarily reflect the views of the Swiss National Bank. The SNB takes no responsibility for any errors or omissions in, or for the correctness of, the information contained in this paper.

\section{References}

Afonso, A., Furceri, D., \& Gomes, P. (2012). Sovereign credit ratings and financial markets linkages: Application to European data. Journal of International Money and Finance, 31(3), 606-638. https://doi.org/10.1016/j.jimonfin.2012.01.016

Afonso, A., Gomes, P., \& Rother, P. (2007). What 'hides' behind sovereign debt ratings? Working Paper Series 711, European Central Bank. Available: https://www.ecb.europa.eu/ pub/pdf/scpwps/ecbwp711.pdf?6dcb8c9f1f85e3a95e9687ddd523a402 ( July 20, 2012).

Aizenman, J., Binici, M., \& Hutchison, M. M. (2013a). Credit ratings and the pricing of 
sovereign debt during the euro crisis. Technical Report, National Bureau of Economic Research. https://doi.org/10.1093/oxrep/grt036

Aizenman, J., Hutchison, M., \& Jinjarak, Y. (2013b). What is the risk of European sovereign debt defaults? Fiscal space, CDS spreads and market pricing of risk. Journal of International Money and Finance, 34(3), 37-59. http://dx.doi.org/10.1016/ j.jimonfin.2012.11.011

Arellano, M. (1987). Computing robust standard errors for within-groups estimators. Oxford Bulletin of Economics and Statistics, 49(4), 431-434. https://doi.org/10.1111/j.14680084.1987. mp49004006.x

Arezki, R., Candelon, B., \& Sy, A. N. R. (2011). Sovereign rating news and financial markets spillovers: Evidence from the European debt crisis. IMF Working Papers 11/68, International Monetary Fund. Available: https://www.imf.org/external/pubs/ft/wp/2011/ wp1168.pdf (July 22, 2012).

Beetsma, R., Giuliodori, M., de Jong, F., \& Widijanto, D. (2013). Spread the news: The impact of news on the european sovereign bond markets during the crisis. Journal of International Money and Finance, 34(3), 83-101. http://dx.doi.org/10.1016/j.jimonfin. 2012.11.005.

Beirne, J. and Fratzscher, M. (2013). The pricing of sovereign risk and contagion during the european sovereign debt crisis. Journal of International Money and Finance, 34(3), 60-82. http://dx.doi.org/10.1016/j.jimonfin.2012.11.004

Blanchard, O. (2011). 2011 in review: Four hard truths. iMF direct. Available: https:// blog-imfdirect.imf.org/2011/12/21/2011-in-review-four-hard-truths/ (February 8, 2012).

Bloomberg (2011). S\&P roils global markets with erroneous message on French rating. Found April 3, 2012: www.bloomberg.com. Not publicly available any longer.

Calvo, G. A. (1988). Servicing the public debt: The role of expectations. American Economic Review, 78(4), 647-661. Available: http://www.jstor.org/stable/1811165 (March 3, 20012)

Cantor, R. and Packer, F. (1996). Determinants and impact of sovereign credit ratings. Economic Policy Review, 2(2), 37-53. https://doi.org/10.2139/ssrn.1028774

Cole, H. L. and Kehoe, T. J. (2000). Self-fulfilling debt crises. Review of Economic Studies, 67(1), 91-116. https://doi.org/10.1111/1467-937X.00123

Davies, R. B. (1987). Hypothesis testing when a nuisance parameter is present only under the alternative. Biometrika, 74(1), 33-43. https://doi.org/10.2307/2336019

De Grauwe, P. (2011). A fragile eurozone in search of a better governance. CESifo Working Pape 3456. Available: https://www.cesifo-group.de/DocDL/cesifo1_wp3456.pdf (May 7, 2012).

De Grauwe, P. and Ji, Y. (2012). Mispricing of Sovereign Risk and Multiple Equilibria in the Eurozone. LICOS Discussion Paper No. 304. http://dx.doi.org/10.2139/ssrn.1996396 
De Grauwe, P. and Ji, Y. (2013). Self-fulfilling crises in the eurozone: An empirical test. Journal of International Money and Finance, 34(3), 15-36. https://doi.org/10.2139/ ssrn.2122899

De Walque, G., Pierrard, O., \& Rouabah, A. (2010). Financial (in)stability, supervision and liquidity injections: A dynamic general equilibrium approach. Economic Journal, 120(549), 1234-1261. https://doi.org/10.1111/j.1468-0297.2010.02383.x

Eichberger, J. and Summer, M. (2005). Bank capital, liquidity, and systemic risk. Journal of the European Economic Association, 3(2-3), 547-555. https://doi.org/10.1162/ jeea.2005.3. $2-3.547$

Eichengreen, B. and Mody, A. (2000). What explains changing spreads on emerging market debt? In S. Edwards (Ed.), Capital Flows and the Emerging Economies: Theory, Evidence, and Controversies (pp. 107-136). Chicago: University of Chicago Press.

El-Shagi, M. (2010). The role of rating agencies in financial crises: event studies from the Asian flu. Cambridge Journal of Economics, 34(4), 671-685. https://doi.org/10.1093/ je/ bep049

Escolano, J. (2010). A practical guide to public debt dynamics, fiscal sustainability, and cyclical adjustment of budgetary aggregates. Technical Notes and Manuals 10, International Monetary Fund. https://doi.org/10.5089/9781462396955.005

ESMA (2013). Credit rating agencies: Sovereign ratings investigation. ESMA's assessment of governance, conflicts of interest, resourcing adequacy and confidentiality controls. Available: https://www.esma.europa.eu/system/files_force/library/2015/11/2013-1780_esma_identifies_ deficiencies_in_cras_sovereign_ratings_processes.pdf?download=1 (January 10, 2014).

European Commission (2013). Stricter rules for credit rating agencies to enter into force. Press release. Available: http://europa.eu/rapid/press-release_IP-13-555_en.pdf. (June 18 2013).

Ferri, G., Liu, L.-G., \& Stiglitz, J. E. (1999). The procyclical role of rating agencies: Evidence from the East Asian crisis. Economic Notes, 28(3), 335-355. https://doi.org/ 10.1111/1468-0300.00016

Fitch, Inc. (2011). Fitch sovereign ratings - rating methodology. Found June 6, 2011: https://www.fitchratings.com. Not publicly available any longer.

Gaillard, N. (2011). A Century of Sovereign Ratings. New York et al: Springer.

Gärtner, M., Griesbach, B., \& Jung, F. (2011). Pigs or lambs? the European sovereign debt crisis and the role of rating agencies. International Advances in Economic Research, 17(3), 288-299. https://doi.org/10.1007/s11294-011-9302-7

Gärtner, M., Griesbach, B, \& Mennillo, J. (2014) The near-death experience of the Celtic tiger. A model-driven narrative from the European sovereign debt crisis. Intereconomics, 48(6), 358-365. https://doi.org/10.1007/s10272-013-0478-3 


\section{Mll Macrothink}

Business and Economic Research ISSN 2162-4860 2016, Vol. 6, No. 2

Gerlach, S. (2010). The Greek sovereign debt crisis and ECB policy. Report for the European Parliament's Committee on Economic and Monetary Affairs. http://www.europarl.europa.eu/ document/activities/cont/201006/20100610ATT75778/20100610ATT75778EN.pdf

Gros, D. (2012). A simple model of multiple equilibria and default. CEPS working document no. 366. Available: https://www.ceps.eu/system/files/WD366\%20DG\%20Multiple\% 20Equilibria.pdf (November 17, 2016).

Haruvy, E., Lahav, Y., \& Noussair, C. N. (2007). Traders' expectations in asset markets: Experimental evidence. American Economic Review, 97(5), 1901-1920. https://doi.org/ 10.1257/aer.97.5.1901

Hastie, T. and Tibshirani, R. (1990). Generalized additive models. Monographs on Statistics and Applied Probability. London: Taylor \& Francis.

Kaminsky, G. and Schmukler, S. L. (2002). Emerging market instability: Do sovereign ratings affect country risk and stock returns? World Bank Economic Review, 16(2), 171-195. https://doi.org/10.1093/wber/16.2.171

Kashyap, A. and Stein, J. C. (2004). Cyclical implications of the Basel II capital standards. Economic Perspectives, 28 (1), 18-31. http://www.chicagofed.org/digital_assets/publications/ economic_perspectives/2004/ep_1qtr2004_part2_kashyap_stein.pdf

Kiff, J., Nowak, S. B., \& Schumacher, L. (2012). Are rating agencies powerful? An investigation into the impact and accuracy of sovereign ratings. IMF Working Papers 12/23, International Monetary Fund. Available: https://www.imf.org/external/pubs/ft/wp/2012/ wp1223.pdf

Kliger, D. and Sarig, O. (2000). The information value of bond ratings. Journal of Finance, 55(6), 2879-2902. https://doi.org/10.1111/0022-1082.00311

Krugman, P. (1996). Are currency crises self-fulfilling? In B. Bernanke and J. Rothemberg (Eds.), NBER Macroeconomics Annual, 11, 345-407. https://doi.org/10.1086/654311

Krugman, P. (2011). Wonking about the euro crisis. The New York Times Opinion Pages, Available: http://krugman.blogs.nytimes.com/2011/08/08/wonking-out-about-the-euro-crisisvery-wonkish/?_r=0 (January 26, 2012).

Manganelli, S. and Wolswijk, G. (2009). What drives spreads in the euro area government bond market? Economic Policy, 24, 191-240. https://doi.org/10.1111/j.1468-0327.2009. 00220.x

Mellios, C., \& Paget-Blanc, E. (2006). Which factors determine sovereign credit ratings? European Journal of Finance, 12(4), 361-377. https://doi.org/10.1080/13518470500377406

Muggeo, V. M. R. (2003). Estimating regression models with unknown break-points. Statistics in Medicine, 22(19), 3055-3071. https://doi.org/10.1002/sim.1545

Muggeo, V. M. R. (2008). Segmented: an R package to fit regression models with broken-line relationships. $R$ News, $8(1), 20-25$. https:/www.researchgate.net/profile/Vito_Muggeo/ 
publication/234092680_Segmented_An_R_Package_to_Fit_Regression_Models_With_Brok en-Line_Relationships/links/540f1de30cf2df04e75a254a.pdf?origin=publication_detail

Newey, W. K. and West, K. D. (1987). A simple, positive semi-definite, heteroskedasticity and autocorrelation consistent covariance matrix. Econometrica, 55(3), 703-08. https://doi. org/10.2307/1913610

Pederzoli, C., Torricelli, C., \& Tsomocos, D. (2010). Rating systems, procyclicality and basel ii: an evaluation in a general equilibrium framework. Annals of Finance, 6(1), 33-49. https:// doi.org/10.1007/s10436-009-0128-8

Reisen, H. and von Maltzan, J. (1999). Boom and bust and sovereign ratings. International Finance, 2(2), 273-293. https://doi.org/10.1787/251521656447

Romer, D. (2012). Advanced Macroeconomics, $4^{\text {th }}$ ed., pp. 632-639. New York: McGraw-Hill Irwin.

Schumacher, I. (2014). On the self-fulfilling prophecy of changes in sovereign ratings. Economic Modelling, 38(2), 351-356. https://doi.org/10.1016/j.econmod.2014.01.012

Soros, G. (2012). Challenging the Foundation. INET Annual Conference, Berlin. Available : https://www.cigionline.org/multimedia/george-soros-challenging-foundation.

The Economist (2005). Credit-rating agencies. Three is no crowd: 23 March. Available: http://www.economist.com/node/3789445

The Economist (2011). The illustrated euro crisis: multiple equilibria. Blog entry, Available: http://www.economist.com/blogs/freeexchange/2011/10/illustrated-euro-crisis (February 8, 2012.

von Hagen, J., Schuknecht, L., \& Wolswijk, G. (2011). Government bond risk premiums in the EU revisited: The impact of the financial crisis. European Journal of Political Economy, 27(1), 36-43. https://doi.org/10.1016/j.ejpoleco.2010.07.002

Wooldridge, J. (2002). Econometric Analysis of Cross Section and Panel Data. Cambridge, Mass.: The MIT Press.

Xia, H. and Strobl, G. (2012). The issuer-pays rating model and ratings inflation: Evidence from corporate credit ratings. SSRN.Electronic Journal. https://doi.org/10.2139/ssrn.2002186

Zeileis, A. (2004). Econometric computing with hc and hac covariance matrix estimators. Journal of Statistical Software, 11(10), 1-17. https://doi.org/10.18637/jss.v011.i10

\section{Appendices}

Appendix 1. Robustness checks

- Fixed effects: Tables 5 and 6 show fixed effect regressions analogous to the pooled OLS regressions used in the text (see Table 2 and 3). A Hausman test indicates in all cases to use fixed over random effects. The tables show heteroscedasticity and serial correlation consistent standard errors for within-group estimators as suggested by Arellano (1987). The 
coefficients of the most important regressors, interest rate and rating, remain largely robust. We also conducted the Davies (1987) test on the fixed effects model. Here, the null of a linear effect of the interest rate on ratings is rejected at the $5 \%$ level. The threshold lies at an interest rate of $4.8 \%$. However, since a segmented regression reveals that the $r$ line actually turns flatter beyond this threshold, this non-linearity exacerbates the risk of multiple equilibria.

Table 5. Regressions explaining sovereign debt ratings with fixed effects. Endogenous variable: sovereign debt rating $r$. Annual data for 25 OECD countries, 1999-2011

\begin{tabular}{|l|l|l|l|}
\hline & $(1)$ & $(2)$ & $(3)$ \\
\hline GDP growth & -0.077 & $0.232^{* * *}$ & -0.098 \\
& $(0.071)$ & $(0.084)$ & $(0.090)$ \\
\hline GDP per capita & 0.026 & $-0.144^{* * *}$ & $-0.122^{* *}$ \\
& $(0.036)$ & $(0.034)$ & $(0.053)$ \\
\hline Budget surplus & $-0.074 *$ & 0.012 & $-0.087 * * *$ \\
& $(0.043)$ & $(0.056)$ & $(0.029)$ \\
\hline Debt ratio & $0.047^{* * *}$ & $0.030^{* * *}$ & $0.037 * * *$ \\
& $(0.013)$ & $(0.009)$ & $(0.010)$ \\
\hline Primary surplus & $0.221^{* * *}$ & -0.087 & $0.163 * * *$ \\
& $(0.076)$ & $(0.065)$ & $(0.054)$ \\
\hline Inflation & -0.074 & -0.093 & -0.127 \\
& $(0.069)$ & $(0.108)$ & $(0.084)$ \\
\hline & $0.415 * *$ & $0.987 * * *$ & $0.571^{* *}$ \\
& $(0.199)$ & $(0.246)$ & $(0.268)$ \\
\hline Country FE & Yes & No & Yes \\
\hline Time FE & No & Yes & Yes \\
\hline Within $R^{2}$ & 0.549 & 0.735 & 0.589 \\
\hline Adjusted within $R^{2}$ & 0.489 & 0.687 & 0.502 \\
\hline F & 45.128 & 107.579 & 50.731 \\
\hline Observations & 291 & 291 & 291 \\
\hline & & & \\
\hline
\end{tabular}

Fixed effect regressions. $\bar{i}$ denotes annual averages of government bond yields. Arellano (1987) heteroscedasticity and serial correlation robust standard errors in parentheses. $*, * *, * * *$ denote significance at the $10 \%, 5 \%, 1 \%$ levels. Ratings are transformed into an equidistant numerical scale from 1 (AAA) to 21 (D), see Appendix 2 for entire table.

Some of the remaining explanatory variables, despite being less important for our main result, apparently do change when employing fixed effects. The most notable difference is that primary surplus in the rating regression switches the sign which is against intuition and to which we do not have a clear answer, unfortunately.

- 2SLS with fixed effects: Table 7 shows 2 SLS regressions with country fixed effects (using dummy variables) analogous to the 2SLS regressions in the text (see Tables 2 and 3). The relevant coefficients of interest rate and rating remain significant at the $6 \%$ and $1 \%$ level. 


\section{NI Macrothink}

Business and Economic Research

ISSN 2162-4860 2016, Vol. 6, No. 2

Table 6. The effect of ratings on sovereign bond yields, fixed effects. Endogenous variable: credit spread of government bonds $i-i_{D}$. Annual data, 25 OECD countries, 1999-2011.

\begin{tabular}{|l|l|l|l|}
\hline & $(1)$ & $(2)$ & $(3)$ \\
\hline$r^{3}$ & $\begin{array}{l}0.006^{* * *} \\
(0.000)\end{array}$ & $\begin{array}{l}0.006^{* * *} \\
(0.000)\end{array}$ & $\begin{array}{l}0.006^{* * *} \\
(0.000)\end{array}$ \\
\hline Country FE & Yes & No & Yes \\
\hline Time FE & No & Yes & Yes \\
\hline$R^{2}$ & 0.880 & 0.800 & 0.898 \\
\hline Adjusted $R^{2}$ & 0.802 & 0.764 & 0.783 \\
\hline F & 1950.285 & 1111.985 & 2226.446 \\
\hline Observations & 291 & 291 & 291 \\
\hline
\end{tabular}

Fixed effect regressions. The dependent variable is credit spread $i-i_{D}, r$ denotes sovereign debt rating. Arellano (1987) heteroscedasticity and serial correlation robust standard errors in parentheses. *, **, $* * *$ denote significance at the $10 \%, 5 \%, 1 \%$ levels. See also notes to Table 5 .

- Cross sectional analysis: Tables 8 and 9 re-estimate regression I of Table 2 and IV from Table 3 with cross-section data only, showing a pre-crisis and a crisis year. Results suggest that in the absence of potential deficiencies due to the use of time series data, the qualitative properties of the model remain fairly robust. This also holds for other years and subsamples in our panel.

- Generalized additive model: We also estimated a generalized additive model (GAM) to the data. GAMs are generalized linear models in which the linear predictor is given by a sum of smoothing functions of the regressors instead of simple coefficients. ${ }^{25}$ Here we use penalized regression splines with four degrees of freedom. The estimated results for the interest rate equation from section 2.3 are shown in Table 10. Figure 3 highlights again the nonlinear relationship between the current rating and the current credit spread on government bonds. Analogous to the interest rate equation, we also fitted a generalized additive model to find a non-parametric estimate of the functional form in the rating equation discussed in section 2.2. The result matched our previous finding from the Davies test in section 2.2 by showing an almost perfectly linear relationship.

- Eurozone analysis: Table 11 re-estimates regressions 1 of Table 2 and 4 from Table 3 with data from eurozone countries only. ${ }^{26}$ The regressions show that when excluding any potential exchange rate risk from the data, the main results remain valid.

- Evidence on the causal effect of ratings on interest rates: Statistical tests provide pieces of evidence, but will always remain vulnerable to issues that may result from omitted variables. In addition, statistical tests of causality in fast-moving financial markets, such as

\footnotetext{
${ }^{25}$ See Hastie and Tibshirani (1990). Results of GAMs, in general, have to be taken with care, however, since they are prone to over-fitting the data.

${ }^{26}$ Eurozone countries in this sample are the eleven founding states Belgium, Germany, Finnland, France, Ireland, Italy, Luxembourg, Netherlands, Austria, Portugal and Spain, as well as Greece that joined the eurozone in 2001.
} 


\section{Macrothink Institute ${ }^{\mathrm{TM}}$}

the market for governments bonds, may hide short-run effects when the inclusion of macroeconomic variables calls for the use of annual data. In order to augment the evidence provided, we take a look at results provided by studies of higher-frequency data and by institutional arguments.

Table 7. 2SLS regression with country fixed effects. Endogenous variables: $r, i$. Annual data for 25 OECD countries, 1999-2011

\begin{tabular}{|l|l|l|}
\hline & $(r)$ & $(i)$ \\
\hline Constant & $\begin{array}{l}1.810^{* *} \\
(0.879)\end{array}$ & $\begin{array}{l}1.511^{* * *} \\
(0.214)\end{array}$ \\
\hline GDP growth & $\begin{array}{l}-0.097^{*} \\
(0.051)\end{array}$ & - \\
\hline GDP per capita & $\begin{array}{l}-0.024 \\
(0.016)\end{array}$ & - \\
\hline Budget surplus & $\begin{array}{l}-0.069^{* *} \\
(0.027)\end{array}$ & - \\
\hline Debt ratio & $\begin{array}{l}0.042^{* * *} \\
(0.006)\end{array}$ & - \\
\hline Primary surplus & $\begin{array}{l}0.189^{* * *} \\
(0.051)\end{array}$ & - \\
\hline Inflation & -0.051 & - \\
& $(0.045)$ & \\
\hline$i$ & $0.143^{*}$ & - \\
$(0.074)$ & \\
\hline$r^{3}$ & - & $\begin{array}{l}0.007 * * * \\
(0.000)\end{array}$ \\
\hline Country FE & Yes & Yes \\
\hline Time FE & No & No \\
\hline$R^{2}$ & 0.939 & 0.892 \\
\hline Adjusted $R^{2}$ & 0.931 & 0.882 \\
\hline Observations & 291 & 291 \\
\hline & & \\
\hline
\end{tabular}

2SLS regressions with country fixed effects using dummy variables. $i$ denotes (end of year) government bond yield. $r$ denotes sovereign debt rating. Standard errors in parentheses. ${ }^{*}, * *, * * *$ denote significance at the $10 \%$, $5 \%, 1 \%$ levels. Instruments include linear and cubic terms of all exogenous variables. See notes to Table $5 .$.

Kaminsky and Schmukler (2002) provide evidence that changes in sovereign debt ratings affect the prices of bonds. This study focuses on emerging markets in the last decade of the twentieth century. Reisen and von Maltzan (1999) report similar results but focus on the East Asian crisis. Arezki et al. (2011) show that there is an impact of rating news on credit markets in Europe during the time span 2006-2011. Afonso et al. (2012) support this finding while working with a a different data set which lasts from 1995 until 2010. Most of these studies 
use daily data in a VAR framework and apply Granger-causality tests. Gärtner et al. (2011) report two-way causality, with stronger evidence in support of causality running from ratings to government bond yields. ${ }^{27}$

Table 8. Regressions explaining sovereign debt ratings in a cross sectional analysis. Endogenous variable: sovereign debt rating $r 25$ OECD countries (selected years)

\begin{tabular}{|l|l|l|}
\hline & $(2010)$ & $(2002)$ \\
\hline Constant & -3.686 & 1.439 \\
& $(3.587)$ & $(2.581)$ \\
\hline GDP growth & 0.238 & $0.412^{*}$ \\
& $(0.312)$ & $(0.209)$ \\
\hline GDP per capita & -0.047 & $-0.164 * * *$ \\
& $(0.058)$ & $(0.050)$ \\
\hline Budget surplus & -0.100 & 0.046 \\
& $(0.075)$ & $(0.090)$ \\
\hline Debt ratio & $0.032^{* *}$ & $0.027 * *$ \\
& $(0.012)$ & $(0.010)$ \\
\hline Primary surplus & 0.116 & -0.084 \\
& $(0.154)$ & $(0.093)$ \\
\hline Inflation & -0.136 & -0.117 \\
& $(0.367)$ & $(0.211)$ \\
\hline $\bar{i}_{-1}$ & $1.381^{* * *}$ & $0.548 * * *$ \\
& $(0.392)$ & $(0.176)$ \\
\hline$R^{2}$ & 0.767 & 0.843 \\
\hline Adjusted $R^{2}$ & 0.671 & 0.774 \\
\hline F & 8.006 & 12.250 \\
\hline Observations & 25 & 24 \\
\hline & & \\
\hline
\end{tabular}

OLS regressions. $\bar{i}$ denotes annual average of government bond yields. Standard errors in parentheses. *, **, *** denote significance at the $10 \%, 5 \%, 1 \%$ levels. See notes to Table 5 .

Looking at corporate ratings instead of sovereign ratings Kliger and Sarig (2000) study Moody's refinement of its rating system in 1982. Even though the underlying fundamental probability of default was not affected, the rating changes triggered significant price changes, leading to the conclusion that ratings do have a causal effect. A similar, exogenous rating event that has not yet been investigated statistically, is the erroneous rating downgrade of France on November 10, 2011: By mistake Standard \& Poors announced that France was downgraded from AAA to AA+. Two hours later this announcement was withdrawn and France's top rating was reaffirmed. During these two hours, French government bond yields

\footnotetext{
${ }^{27}$ Several other studies emphasize the impact of rating agencies in credit markets such as Eichengreen and Mody (2000), Ferri et al. (1999), Manganelli and Wolswijk (2009) and Kiff et al. (2012).
} 
had surged to a five month high. ${ }^{28}$.

Table 9. The effect of ratings on sovereign bond yields.Cross sectional analysis. Endogenous variable: Credit spread of government bonds $i-i_{D} .25$ OECD countries (selected years)

\begin{tabular}{|l|l|l|}
\hline & $(2010)$ & $(2002)$ \\
\hline Constant & $0.607 * *$ & 0.176 \\
& $(0.271)$ & $(0.252)$ \\
\hline$r^{3}$ & $0.008^{* * *}$ & $0.003^{*}$ \\
& $(0.001)$ & $(0.002)$ \\
\hline$R^{2}$ & 0.764 & 0.139 \\
\hline Adjusted $R^{2}$ & 0.753 & 0.100 \\
\hline F & 74.316 & 3.564 \\
\hline Observations & 25 & 24 \\
\hline
\end{tabular}

OLS regressions. The dependent variable is credit spread $i-i_{D}, r$ denotes sovereign debt rating. Standard errors in parentheses. *,**,*** denote significance at the $10 \%, 5 \%, 1 \%$ levels. See notes to Table 5 .

Moreover, one can also argue that institutional factors necessarily lead to a causal relationship from ratings onto interest rates. The Basel II framework forces European banks to keep a minimum capital ratio of $8 \%$. This capital ratio is calculated using a risk weighted sum of total assets to which ratings by the three big agencies have to be taken into account as long as a bank cannot provide its own rating. Secondly, the European Central Bank, but also other financial institutions are forced by law to only accept investment grade securities (BBB or better) for repurchase agreements. A downgrade close to or below that threshold, therefore, forces fire sales of the respective security which deteriorates prices and increases interest rates, respectively. Early warnings about this issue can be found in Kashyap and Stein (2004) who anticipate that Basel II will "exacerbate business cycle fluctuations". Other authors, such as Eichberger and Summer (2005), Pederzoli et al. (2010) and de Walque et al. (2010) also emphasized this threat.

Table 10. GAM regresssions explaining current credit spreads. Endogenous variable: credit spread of government bonds $i-i_{D} .2010$ data for 25 OECD countries

\begin{tabular}{|l|l|l|}
\hline & $E D F$ & $p$-value \\
\hline $\mathrm{s}(\mathrm{r})$ & 2.956 & $0.000^{* * *}$ \\
\hline adjusted $R^{2}$ & 0.806 \\
\hline Observations & 291 \\
\hline
\end{tabular}

Genaralized additive model. $r$ denotes sovereign debt rating. Standard errors in parentheses. *, **, *** denote significance at the $10 \%, 5 \%, 1 \%$ levels. $E D F$ stands for effective degrees of freedom.

${ }^{28}$ See Bloomberg (2011) 


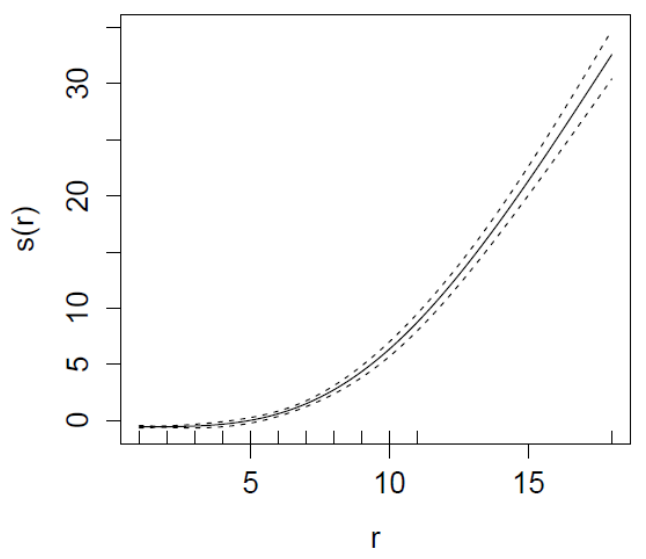

Figure 3. Spline estimation of the rating $r$ from the GAM regression shown in Table 11. Thin lines show $90 \%$ confidence bands

Table 11. The analysis with countries of the eurozone only Endogenous variables: $r, i-i_{D}$. Annual data for 12 eurozone countries, 1999-2011

\begin{tabular}{|c|c|c|}
\hline & $(r)$ & $\left(i-i_{D}\right)$ \\
\hline Constant & $\begin{array}{l}-6.904 * * * \\
(2.620)\end{array}$ & $\begin{array}{l}0.336 * * * \\
(0.097)\end{array}$ \\
\hline GDP growth & $\begin{array}{l}-0.021 \\
(0.135)\end{array}$ & - \\
\hline GDP per capita & $\begin{array}{l}0.002 \\
(0.035)\end{array}$ & - \\
\hline Budget surplus & $\begin{array}{l}-0.167 * * * \\
(0.046)\end{array}$ & - \\
\hline Debt ratio & $\begin{array}{l}0.044 * * * \\
(0.008)\end{array}$ & - \\
\hline Primary surplus & $\begin{array}{l}0.034 \\
(0.071)\end{array}$ & - \\
\hline Inflation & $\begin{array}{l}0.359^{* *} \\
(0.163)\end{array}$ & - \\
\hline $\bar{i}_{-1}$ & $\begin{array}{l}1.033 * * * \\
(0.356)\end{array}$ & - \\
\hline$r^{3}$ & - & $\begin{array}{l}0.006^{* * * *} \\
(0.000)\end{array}$ \\
\hline$R^{2}$ & 0.749 & 0.918 \\
\hline adjusted $R^{2}$ & 0.734 & 0.917 \\
\hline $\mathrm{F}$ & 16.421 & 654.015 \\
\hline Observations & 132 & 132 \\
\hline
\end{tabular}

OLS regressions. $r$ denotes sovereign debt rating and $i-i_{D}$ credit spread. Heteroscedasticity and autocorrelation robust standard errors in parentheses as documented in Zeileis (2004). *, **, *** denote significance at the $10 \%, 5 \%, 1 \%$ levels. See notes to Table 5 . 
Appendix 2. Rating conversion

Table 12 shows the conversion of ratings into an equidistant numerical scale similiar to Afonso et al. (2007).

Table 12. Rating conversion

\begin{tabular}{|l|l|}
\hline Rating & Numerical value \\
\hline AAA & 1 \\
\hline AA+ & 2 \\
\hline AA & 3 \\
\hline AA- & 4 \\
\hline A+ & 5 \\
\hline A & 6 \\
\hline A- & 7 \\
\hline BBB+ & 8 \\
\hline BBB & 9 \\
\hline BBB- & 10 \\
\hline BB+ & 11 \\
\hline BB & 12 \\
\hline BB- & 13 \\
\hline B+ & 14 \\
\hline B & 15 \\
\hline B- & 16 \\
\hline CCC+ & 17 \\
\hline CCC & 18 \\
\hline CCC- & 19 \\
\hline CC & 20 \\
\hline C & 20 \\
\hline RD & 21 \\
\hline DDD & 21 \\
\hline DD & 21 \\
\hline D & 21 \\
\hline & \\
\hline
\end{tabular}

\section{Copyright Disclaimer}

Copyright for this article is retained by the author(s), with first publication rights granted to the journal.

This is an open-access article distributed under the terms and conditions of the Creative Commons Attribution license (http://creativecommons.org/licenses/by/3.0/). 